\title{
Revisiting Sproles and Kendall's Consumer Styles Inventory (CSI) in the 21st Century: A Case of Australian Consumers Decision-Making Styles in the Context of High and Low-Involvement Purchases
}

\author{
${ }^{1}$ Tahmid Nayeem, ${ }^{2}$ Jean Marie-IpSooching \\ ${ }^{I}$ School of Business, Charles Sturt University, Elizabeth Mitchell Drive, ALBURY NSW 2640, Australia \\ ${ }^{2}$ Lyons College, Melbourne VIC 3000
}

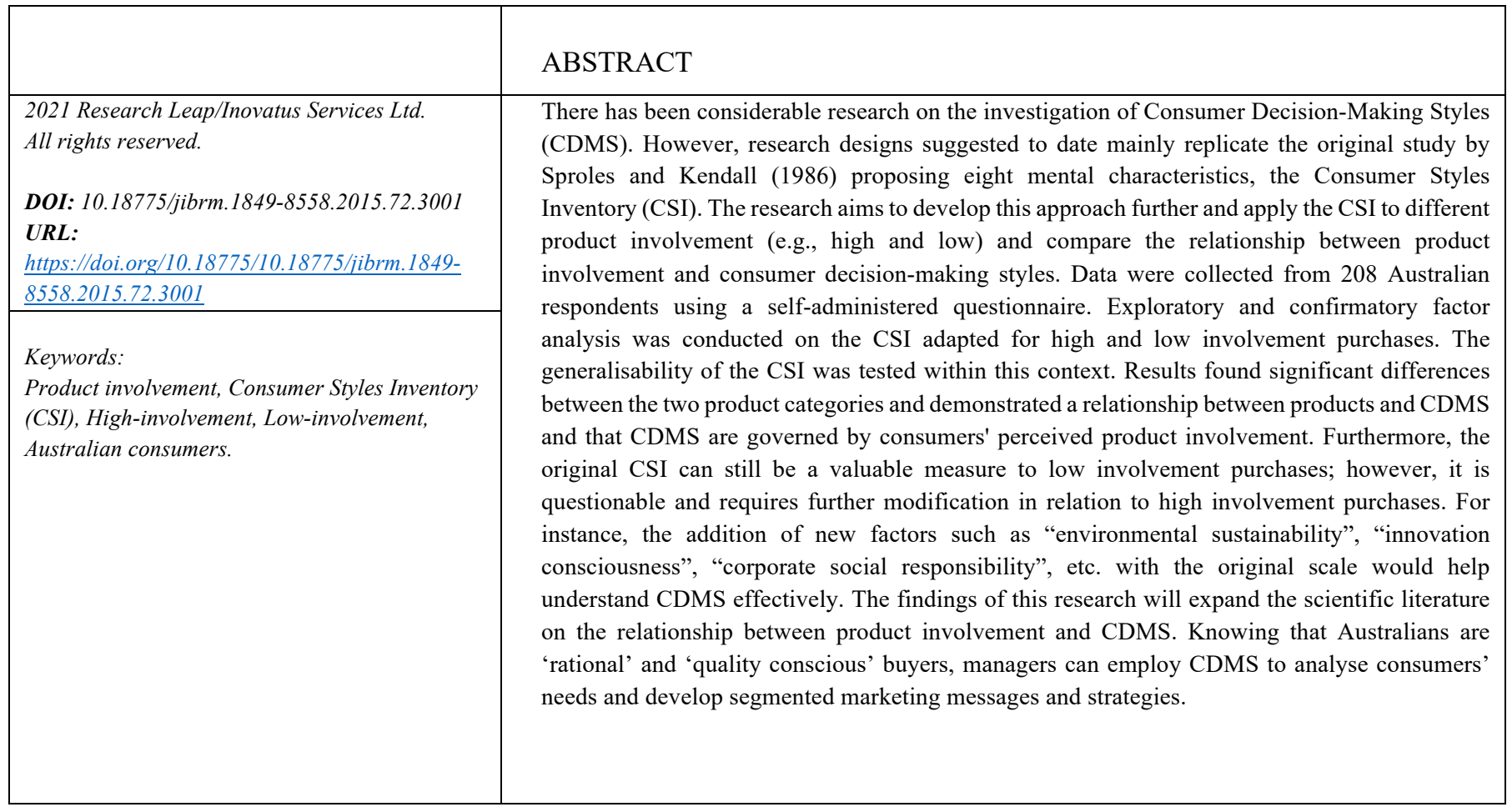

\section{Introduction}

The investigation of consumer decision-making has a long tradition in marketing and consumer behaviour research (Bauer et al., 2006; Lysonski and Durvasula 2013; Rezaei, 2015). It is useful to identify consumers' decision-making styles (CDMS), so advertisers and marketers can use such a profile to segment consumers into profitable clusters (Lysonski et al., 1996; Nayeem and Casidy 2015). Consumers' decision-making styles influence how they negotiate their way through the decisionmaking process; for example, how they approach the information search, evaluation and selection, while also shaping their purchase behaviour (Nayeem, 2012). The characteristics of decision-making styles can be useful in profiling an individual's consumer style in terms of his/her product evaluation and selection process (Canabal 2002; Hanzaee and Aghasibeig 2008).
Consumer decision-making styles can be defined as a cognitive and affective or 'mental' orientation characterising a consumer's approach to the overall decision-making process (Sproles and Kendall 1986). People may have more than one decision-making style, and it may change depending on the product. These styles may vary across different product categories (Bauer et al., 2006). For example, consumers may be more brand conscious for high involvement product categories, whereas low involvement product decisions may be more affected by price. Consumers can also be quality and priceconscious in their decision-making styles when they are familiar with particular product categories and brands. (Leo et al., 2005). With this in mind, Sproles and Kendall (1986) developed a measure (the CSI), which can be used to identify the characteristics of CDMS. (Radder and Pieterson 2006; Hanzaee and Aghasibeig 2008; Azizi and Makkizadeh 2012). 
However, the CSI has not been found to be completely reliable (Bauer et al., 2006; Tanksale et al., 2014). It is unclear whether the CSI, mostly validated with student samples, is suitable for different types of consumers. The CSI needed to be tested on non-student samples to establish its generalisability to broader consumer groups (Leo et al., 2005; Nayeem and Casidy 2015). A further limitation of the CSI is that it measures general shopping orientation, with studies focusing on non-specific product types (Mitchell and Bates 1998; Nayeem and Casidy 2013). A small number of studies have examined the CSI in relation to low involvement purchases (see Leo et al., 2005; Radder et al., 2006; Nayeem and Casidy 2015). However, there are not enough studies that have established the validity of the CSI in the context of high involvement purchases or using Australian samples (Nayeem and Casidy 2015). Another problem is that the CSI factor structure is unstable (Lysonski et al., 1998; Radder, Li and Pietersen 2006). Besides, one of the shortcomings of Sproles and Kendall's (1986) CSI can be found in the formulation of the items, which leads to poor construct validity (number of factors varies across studies) and, as a consequence, in the low to average reliability coefficients (Mitchell and Bates 1998; Hanzaee and Aghasibeig 2008). This also indicates that more improvement and development of the scale is needed.

Furthermore, there is hardly any research on the CSI, which compares high and low involvement purchases, using the same sample or population (Nayeem and Casidy 2015). CDMS for different products are likely to vary depending on the consumers' involvement. For example, consumers are usually more quality conscious and information seekers when purchasing high involvement products (e.g., automobiles) than low involvement products (e.g., confectionary). These findings will expand the scientific literature on the relationship between product involvement and consumer decision-making styles.

In light of the above limitations, the primary purpose of the current research is to apply Sproles and Kendall's (1986) CSI in the context of an automobile and everyday product purchase within the general population of Australian consumers. This research developed a product/s-specific (automobile and confectionary) version of the CSI administered to an adult sample to compare consumer decision-making styles between high-and-low involvement purchases. The generalisability of the CSI was tested within this context. The paper begins with a review of existing literature, an outline of the study's methodology, followed by a discussion of results. The paper concludes with managerial implications, limitations, and directions for future research.

\section{Literature review}

The literature review consists of two sections: an outline of the consumer decision-making styles inventory (CSI), followed by a brief discussion about the significant differences between high and low involvement purchases.

\subsection{Consumer Styles Inventory (CSI)}

The CSI is based on preliminary work done by Sproles (1983), in which he argued that there are certain fundamental styles that all consumers apply to their shopping and buying. These styles included brand, price or quality consciousness and provided a conceptual framework for describing consumer decisionmaking styles. Together with Kendall (1986), Sproles developed a revised model of eight consumer decision-making styles based on cognitive and personality characteristics. Each of these styles independently characterises a fundamental intellectual approach to consumption (Nayeem and Casidy 2015). Sproles and Kendall's (1986) model of eight consumer decision-making styles is shown below.

Table 1: Consumer decision-making styles

\begin{tabular}{|c|c|}
\hline $\begin{array}{l}\text { Consumer } \\
\text { decision-making } \\
\text { styles }\end{array}$ & Definition \\
\hline $\begin{array}{l}\text { Perfectionist, high } \\
\text { quality conscious }\end{array}$ & $\begin{array}{l}\text { Consumer has specific ideas about } \\
\text { best quality products and consistently } \\
\text { looks for these qualities. }\end{array}$ \\
\hline Brand conscious & $\begin{array}{l}\text { Consumer associates quality with } \\
\text { higher priced brands and is expected } \\
\text { to buy expensive, well-known brands. }\end{array}$ \\
\hline Recreational & $\begin{array}{l}\text { Characterises people who are likely } \\
\text { to shop just for fun/leisure and find } \\
\text { shopping pleasant. }\end{array}$ \\
\hline Price conscious & $\begin{array}{l}\text { Consumer consistently searches for } \\
\text { sales, bargains and lower-priced } \\
\text { products. }\end{array}$ \\
\hline Impulsive & $\begin{array}{l}\text { Consumer does not plan their } \\
\text { shopping, and is not concerned with } \\
\text { how much they spend or with value } \\
\text { for money. }\end{array}$ \\
\hline $\begin{array}{l}\text { Confused by } \\
\text { overchoice }\end{array}$ & $\begin{array}{l}\text { Consumer is confused and } \\
\text { overwhelmed with too much product } \\
\text { information and/or too many product } \\
\text { choices. }\end{array}$ \\
\hline $\begin{array}{l}\text { Habitual/brand } \\
\text { loyal } \\
\text { Novelty fashion } \\
\text { conscious }\end{array}$ & $\begin{array}{l}\text { Consumer tends to consistently stick } \\
\text { with the same brand of product. } \\
\text { Consumer is characterised as a } \\
\text { novelty seeker. They find seeking out } \\
\text { new things pleasurable and exciting. }\end{array}$ \\
\hline
\end{tabular}

The CSI has become the most commonly used measure of consumer decision-making styles and has been widely applied and validated in several countries, including Australia, New Zealand, China, India, Malaysia, Korea, Germany and the United States (see Leo et al., 2005; Baoku et al., 2010; Nayeem and Casidy 2015). The CSI has also proven to be a valuable instrument for marketers, enabling the segmentation and positioning of consumers (Bauer et al., 2006). This research aims to use the CSI and apply it to different product involvement, such as high and low involvement purchases. The 
following section discusses the significant differences between high and low involvement purchases.

\subsection{Product Involvement: High vs Low}

Previous studies have classified involvement in the two categories of high- and low-involvement purchases (Holmes and Crocker 2007). Consumer decision-making for high involvement purchases is defined as the thought process of selecting a logical choice from variable options (Browne and Kaldenberg 1997; Grewal et al., 2003). A further comparison has been made between high- and low involvement purchases to explain more clearly. For instance, a high involvement decision may be a durable good (Blackwell et al. 2006) and is a product requiring extensive thought and information search due to its higher price and degree of purchase or social risk (Shamdasani et al., 2001). Prior to a high involvement purchase, consumers usually collect enough information to minimise the risk involved in the purchase act. Consumers likely to follow a certain sequence of learning, evaluate, purchase for high involvement decision-making (Dholakia, 2001). Examples of high involvement decisions may include automobiles, apartments, and luxury goods.

A low involvement decision may be a convenient good (Sullivan, 1990) that is frequently purchased with little risk involved and little/no information required. A low involvement purchases and/or everyday products represent a significant market in Australia. Seventeen per cent of the average Australian household's budget is spent on food and nonalcoholic beverages (Uncles, 2011). While purchasing everyday products is often regarded as a simplified decisionmaking process, recent studies have suggested that there are various levels of involvement in consumer everyday decision making (Kuenzel and Musters 2007).

Product involvement may have implications for CDMS (Bauer et al., 2006). Howard and Sheth (1969) suggested that consumers undergo three strategies to reduce risks associated with the buying situation; extensive problem solving, limited problem solving, and reutilised response behaviour. However, Okumus et al. (2007) argued that this decision-making process occurs only for high involvement purchases such as automobiles. Zaichkowsky (1986) suggested that consumer behaviour for low involvement products is less critical and less time-consuming. Consumers also tend to ignore price (i.e., low price-consciousness) and might eventually make purchase decisions due to aggressive promotional activities (i.e., impulsive choices).

The current research uses automobiles for its complex decisionmaking process (see, Quester et al., 2007) as a high involvement and confectionery as a low involvement purchase. Confectionery is categorised as a low-involvement-hedonic product (Geuens et al., 2011) widely available and generally affordable. Yet, its purchase might be driven by rational and emotional motives, thus representing an ideal research context for this study.

\section{Research Methodology - Materials and Methods}

This research can be classified as replication with modification category, for example, Type III (see Easley et al., 2000). The study uses similar concepts to previous consumer decisionmaking styles research but uses an adapted version of the popular consumer styles inventory (CSI) to compare CDMS for high (e.g., automobiles) and low (e.g., confectionary) involvement product consumers and uses the same sample or population. Also, involving a heterogeneous sample, this study seeks to examine the validity of the CSI items for Australian conditions - specifically, which scale items should be retained from the original CSI, and whether CDMS between high and low involvement purchases differ significantly.

\subsection{Sampling}

Non-probabilistic sampling technique was employed for this research. The sample consisted of 208 Australian consumers (48\%) men and (52\%) women living in Melbourne, Australia. Many criteria had to be met to qualify for inclusion in the research sample. For example, the sample population for this research was Australian-born consumers only. The sampling frame consisted of consumers living in Melbourne, Australia, who were aged between 18 and 75 years, held a current driver's license, purchased confectionary products in the past week, and purchased a car within the past 12 months. It was reasoned that participants would not be able to recall their purchase precisely if automobile purchases had been made more than one to two years previously (Park and Kim 2003). The following Table outlines the demographic characteristics of respondents.

Respondents were asked to think about their recent automobile and confectionary purchase in general. The survey took approximately 40 minutes to complete. Of the 453 surveys distributed for this study, 237 were returned, of which 29 incomplete surveys were discarded, resulting in 238 responses.

\subsection{Measures}

The study used a self-administered questionnaire. The measures were selected to examine Australian consumers' decision-making styles concerning high and low involvement purchases using the same sample or population. The questionnaire was divided into the following three sections.

\subsection{Demographic Questions}

Section One was used to describe the characteristics of the respondents. Participants were asked to provide information about their age, citizenship, country of birth, gender and education.

CSI (Sproles and Kendall 1986) 
Table 2: Demographic characteristics of respondents

\begin{tabular}{|l|l|}
\hline (N= 238) & \multicolumn{2}{|l|}{ Age } \\
\hline $17-25$ & $18.0 \%$ \\
\hline $26-35$ & $41.7 \%$ \\
\hline $36-45$ & $15.0 \%$ \\
\hline $46-55$ & $15.5 \%$ \\
\hline $56-65$ & $7.0 \%$ \\
\hline 65 and above & $2.9 \%$ \\
\hline Gender & $48.2 \%$ \\
\hline Male & $51.8 \%$ \\
\hline Female & $13.0 \%$ \\
\hline Highest education qualifications \\
\hline High school & $15.0 \%$ \\
\hline TAFE & $36.9 \%$ \\
\hline Bachelor degree & $33.9 \%$ \\
\hline Postgraduate degree & $1.2 \%$ \\
\hline Other & $3.2 \%$ \\
\hline Income & $18.0 \%$ \\
\hline Under $\$ 20,000$ & $24.3 \%$ \\
\hline$\$ 20,000-\$ 39,000$ & $21.1 \%$ \\
\hline$\$ 40,000-\$ 59,000$ & $10.9 \%$ \\
\hline$\$ 60,000-\$ 79,000$ & $22.5 \%$ \\
\hline$\$ 80,000-\$ 99,000$ & \\
\hline Over $\$ 100,000$ &
\end{tabular}

Section Two and Three were used to measure respondents' CDMS in the context of automobiles and confectionary purchases. Participants rated their agreement and disagreement with each statement on a six-point scale ranging from "strongly disagree" (1) to "strongly agree" (6).

Section Two (high-involvement): This research retained all of the Sproles and Kendall (1986) subscale except 'novelty'. This scale was excluded because many items were specific to generic purchases and did not apply to automobiles. For example, one of the excluded items was, "I am the kind of person who would try a new product every day". To assess the "novelty" aspect of CDMS for automobiles, one subscale, "innovation consciousness" (nine items; Raju, 1980), was added alongside the seven factors retained from Sproles and Kendall (1986). The innovation conscious decision-making style is the characteristic of consumers who seek novelty and variety in their purchase decisions. Consumers scoring high on this factor enjoy taking chances of buying an unfamiliar brand to get some variety.

Section Three (low-involvement): The consumer styles inventory (CSI) of Sproles and Kendall consists of 45 statements that assess cognitive and affective characteristics of consumers approaches to making choices. Table 3 shows the CSI subscales.
Table 3: CSI subscales: items per scale with sample items

\begin{tabular}{|l|l|l|}
\hline Subscale & $\begin{array}{l}\text { No. of } \\
\text { items }\end{array}$ & Example \\
\hline High involvement (automobile) & \multicolumn{2}{|l|}{} \\
\hline Perfectionist & 8 & Getting very good quality car is very important to me. \\
\hline Brand conscious & 7 & The higher the price of a car, the better its quality. \\
\hline Confused & 4 & The more I learn about cars, the harder it seems to choose the best \\
\hline Brand loyal & 4 & Once I find a car brand I like, I stick with it. \\
\hline Impulsive & 5 & I should plan my shopping for cars more carefully than I do. \\
\hline Innovation conscious & 9 & A new make of car is not something I would be eager to find out about \\
\hline Price & 3 & I prefer to buy cars at sales price. \\
\hline Recreational & 5 & Going shopping for cars is an enjoyable activity for me. \\
\hline Low involvement (confectionary) & \multicolumn{3}{|l|}{} \\
\hline Perfectionist & 8 & I make special effort to choose very best quality products. \\
\hline Brand conscious & 7 & The well-known national brands are the best for me. \\
\hline Confused & 4 & Sometimes it's hard to choose which stores to shop. \\
\hline Brand loyal & 4 & I have favourite brands I buy over and over. \\
\hline Impulsive & 5 & I am impulsive when purchasing. \\
\hline Novelty/fashion conscious & 9 & I am the kind of person who would try a new everyday product. \\
\hline Price & 3 & The lower price products are usually my choice. \\
\hline Recreational & 5 & I enjoy shopping just for the fun of it. \\
\hline *reversed score & \multicolumn{2}{|l}{} \\
\hline
\end{tabular}

\subsection{Data Analysis}

Data were analysed using SPSS for exploratory factor analysis (EFA) and AMOS26 for confirmatory factor analysis (CFA). The purpose of factor analysis is to summarise the interrelationships among many indicator variables in a concise but accurate manner as an aid to conceptualisation (Gorsuch, 1997). Although the CSI is a well-established instrument, there are not enough studies focusing on Australian CDMS. Therefore, it was appropriate to determine which items strongly loaded on each factor with automobiles and everyday products purchase situations before using CFA to confirm a specific factor structure. Reliability analysis was conducted before CFA and is reported in the results section. The factor structure, including discriminant validity, was established using CFA.

\section{Results}

\subsection{High involvement purchase (e.g., automobile):}

\subsubsection{Results of exploratory factor analysis (EFA)}

In the first step of the factor analysis, EFA was conducted on the 45 items of the consumer styles inventory (CSI) using the calibration sample $(\mathrm{N}=208)$ with maximum likelihood extraction and oblique rotation (OBLIMIN). Oblimin rotation is a general form of performing an oblique rotation and is similar in nature to the ortho max orthogonal rotation procedure (Nunally, 1978). Results showed that an eight-factor solution was more interpretable. All eight factors had eigenvalues over 1. Loadings of 0.50 were used as a guideline in the factor analysis (Nunally, 1978). This resulted in removing 11 items, and an accepted seven-factor solution is shown in Table 4.

Only two factors from the original scale were retained: 'brand' and 'habitual' (Sproles and Kendall 1986), and five new factors emerged: 'investigation process', 'information search', 'value within budget', and 'innovation conscious' decision-making styles.

Note that 'Investigating process' (factor 1) had four items from the original CSI 'perfectionist' and one item from the original CSI 'brand'. 'Information search' (factor 2) retained four items from the original CSI 'confused' and one item from the original CSI 'impulsive'. The original CSI's impulsive factor was not supported; none of the items in this factor loaded strongly. 
'Dealer, enjoyment' (factor 3) had retained four items from the original CSI 'recreation' and two items from the original CSI 'impulsive'. 'Value within budget' (factor 4) had retained four items from the original CSI 'impulsive', two items from the original CSI 'price' and one item from the original CSI 'perfectionist'. 'Brand conscious' (factor 5) had retained four items from the original CSI 'brand conscious' and one item from the original CSI 'price'. 'Habitual' (factor 6) had retained three items from the original CSI 'habitual' and one item from the original CSI 'perfectionist'. 'Innovation consciousness' (factor 7) had four items that loaded strongly and, therefore, appeared as one of the crucial factors in relation to automobile purchases.

Table 4: Results of Exploratory factor analysis: 7 factor model

\begin{tabular}{|c|c|}
\hline Factor Characteristics and Items (after EFA) & Factor loadings \\
\hline \multicolumn{2}{|l|}{ Factor 1-Investigation process } \\
\hline Investigating new brands of cars is generally a waste of time (CSI high34)* & .669 \\
\hline I shop quickly for cars, buying the first car or brand I find that seems good enough (CSI high35)* & .651 \\
\hline When it comes to buying a car, in general, I usually try to buy the best overall quality (CSI high40) & .593 \\
\hline I really don't give my car purchases much thought or care (CSI high28)* & .573 \\
\hline Getting a very good quality car is very important to me (CSI high10) & .545 \\
\hline \multicolumn{2}{|l|}{ Factor 2 -Information search } \\
\hline $\begin{array}{l}\text { All the information I get on different cars confuses me (CSI high07) } \\
\text { a }\end{array}$ & .744 \\
\hline The more I learn about cars, the harder it seems to choose the best (CSI high25) & .631. \\
\hline There are so many car brands to choose from that often I feel confused (CSI high32) & .591 \\
\hline It's hard to choose which dealers to shop at for cars (CSI high16) & .581 \\
\hline \multicolumn{2}{|l|}{ Factor 3-Dealer, enjoyment } \\
\hline I take advantage of the first opportunity to find out more about a new dealer selling a car that I & .732 \\
\hline would like to purchase (CSI high39) & 685 \\
\hline I enjoy shopping for cars just for the fun of it (CSI high37) & .611 \\
\hline Going shopping for cars is an enjoyable activity for me (CSI high30) & .591 \\
\hline I am the kind of a person who would try a new make of car (CSI high09) & .544 \\
\hline I would buy a new or different brand of car just to see what it is like (CSI high27) & \\
\hline \multicolumn{2}{|l|}{ Factor 4 -Value within budget } \\
\hline When buying a car, I carefully watch how much I spend (CSI high38) & .531 \\
\hline When shopping for cars, I look carefully to find best value for money (CSI high 14) & .741 \\
\hline I am willing to change brands when buying a new car (CSI high33) & .631 \\
\hline When it comes purchasing cars, I try to get the very best or perfect choice (CSI high45) & .663 \\
\hline When shopping for cars, I take the time to shop carefully for best buys (SCI high24) & .572 \\
\hline When buying a car, I do not want to make a careless purchase I later wish I had not (CSI high15) & .544 \\
\hline I prefer to buy cars at sale price (CSI high03) & .572 \\
\hline \multicolumn{2}{|l|}{ Factor 5 -Brand conscious } \\
\hline A car does not have to be perfect, or the best, to satisfy me (CSI high01)* & .562 \\
\hline The more expensive car brands are usually my choice (CSI high29) & .768 \\
\hline The higher the price of a car, the better its quality (CSI high21) & .771 \\
\hline I go to the same dealer each time I shop for cars (CSI high08) & .691 \\
\hline The lower price cars are usually my choice (CSI high23)* & .678 \\
\hline \multicolumn{2}{|l|}{ Factor 6-Habitual, brand loyal } \\
\hline Once I choose a car brand I like, I stick with it (CSI high26) & .581 \\
\hline I have favourite car brands I buy over and over (CSI high17) & .771 \\
\hline I make a special effort to choose the very best quality cars (CSI high19) & .763 \\
\hline Shopping around dealers wastes my time (CSI high22) & .681 \\
\hline \multicolumn{2}{|l|}{ Factor 7-Innovation conscious } \\
\hline I am the kind of person who would try a new make of car (CSI high02) & .622 \\
\hline I am very cautious about trying new makes of cars (CSI high 11$)^{*}$ & .729 \\
\hline I enjoy taking chances in buying unfamiliar brands of cars just to get some variety (CSI high20) & .727 \\
\hline I would be worried about trying a new make of car (CSI high44)* & .715 \\
\hline
\end{tabular}

The seven-factor solution explained $76 \%$ of the variance. Results of the EFA indicated that many of the factors had good internal consistency, notably 'investigation process' $(\alpha=.766)$, 'information search' ( $\alpha=.733)$, 'value within budget' $(\alpha=$ .719), 'habitual' $(\alpha=.711)$, 'brand' $(\alpha=.779)$, and 'innovation conscious' ( $\alpha=.821)$ decision-making styles. Although, 'dealer, enjoyment' (factor 3) displayed poor internal consistency with a Cronbach's alpha coefficient of .474. Consistent with recent CSI studies (see, Hanzaee and Aghasibeig 2008; Nayeem and Casidy 2015), only factors with Cronbach's alpha $>0.7$ were accepted. Therefore, the 'dealer, enjoyment' decision-making style was not recognised in this study and not included in the CFA.

\subsubsection{Results of Confirmatory Factor Analysis (CFA)}

The next step was CFA. Initially, CFA was conducted for each consumer decision-making style factor by running single factor congeneric models. The indices of goodness-of-fit showed that all the models were satisfactory.

Table 5: Fit statistics for the individual factor of the CFA

\begin{tabular}{llllllll}
\hline Model & CMIN & G & AG & T & C & RMS & SR \\
& /DF & FI & FI & LI & FI & EA & MR \\
Investig & 1.750 & 0. & 0.9 & 0. & 0. & 0.05 & 0.03 \\
ation & & 99 & 4 & 95 & 99 & & \\
process & & & & & & & \\
Informat & 1.733 & 0. & 0.9 & 0. & 0. & 0.05 & 0.03 \\
ion & & 98 & 5 & 94 & 96 & & \\
search & & & & & & & \\
Value & 1.407 & 0. & 0.9 & 0. & 1. & 0.04 & 0.02 \\
within & & 99 & 7 & 99 & 00 & & \\
budget & & & & & & & \\
Brand & 1.607 & 0. & 0.9 & 0. & 0. & 0.05 & 0.04 \\
consciou & & 98 & 5 & 95 & 97 & & \\
s & & & & & & & \\
Habitual & 1.731 & 1. & 0.9 & 1. & 1. & 0.05 & 0.02 \\
& & 00 & 8 & 00 & 00 & & \\
Innovati & 1.651 & 0. & 0.9 & 0. & 0. & 0.04 & 0.03 \\
on & & 99 & 5 & 93 & 98 & & \\
\hline
\end{tabular}

\subsubsection{The Respecified Seven-Factor Model of the CSI}

Finally, the respecified six-factor model of consumer styles inventory consists of 22 items and six factors is shown in figure 1. Overall, twelve items were deleted to achieve a better fit. Two items were removed from the "investigation process" due to insignificant fit as suggested by the MIs (e.g., "CSIhigh28: I really don't give my car purchase much thought or care", CSIhigh10: Getting a very good quality car is very important to me"). Three items were deleted from "value within budget" which improved the model (the items "CSIhigh33: I am willing to change a brand when buying a new car", CSIhigh38 "I enjoy shopping for cars just for the fun of it" and CSIhigh03: "I prefer buying the best-selling car brands"). All five items had retained for the 'brand conscious' decision-making style. However, one item was deleted from the 'habitual, brand loyal' (CSIhigh19 "I make a special effort to choose the very best quality cars"). One item was deleted from the 'innovative conscious' decisionmaking style (CSIhigh11: "I am very cautious about trying new makes of a car").

Chi-square $=2.321 . \mathrm{df}=189, \mathrm{p}=.003, \mathrm{CMIN} / \mathrm{DF}=2.107, \mathrm{GFI}$ $=1.00, \mathrm{AGFI}-.905, \mathrm{TLI}=.921, \mathrm{CFI}=1.00, \mathrm{RMSEA}=.054$ 
Figure 1: A respecified six-factor CFA model of consumer styles inventory (high-involvement purchase)

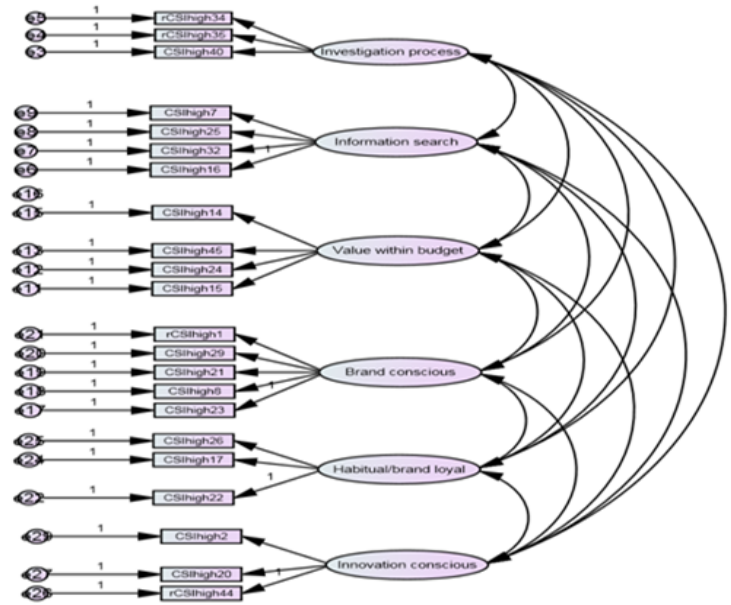

\subsection{Low Involvement Purchase (Everyday Products or Confectionary)}

Results of exploratory factor analysis (EFA)

Following the same approach as previously (see, high involvement), results showed that an eight-factor solution was more interpretable. All eight factors had eigenvalues was over 1. Loadings of 0.50 were used as a guideline in the factor analysis (Nunally, 1978). This resulted in removing 13 items and an accepted eight-factor solution shown in Table 6.

Seven factors from the original scale were retained: 'perfectionist', 'brand', 'confused', 'impulsive', 'habitual', 'novelty' and 'recreation conscious' (Sproles and Kendall 1986) and one new factor 'rational' was developed.

Note that 'perfectionist' (factor 1) retained two items from the original CSI 'perfectionist, high quality' and one from 'impulsive' (reversed item) factor. The 'brand' (factor 2) retained all three items from the original CSI 'brand conscious' decision-making style. 'Confused' (factor 3) has retained all four items from the original 'confused by overchoice' factor.

'Rational' (factor 4) was developed in this study. One item from 'perfectionist', one item from 'novelty' and one item from 'price' were reassigned. Factor 5 'impulsive' had retained one item from the original CSI 'impulsive' factor, one item from 'novelty' and one item from 'perfectionist' (reversed item). 'Habitual' (factor 6) had retained two items from the original CSI 'habitual conscious;' and one from 'novelty/fashionconscious' factor. 'Novelty' (factor 7) had retained two items from the original CSI 'novelty/fashion-conscious' and one item from the 'brand conscious' factor. 'Recreation' (factor 8) had five items that loaded strongly and, therefore, appeared as one of the important factors to everyday products. Four items were retained from the CSI original 'recreation conscious' and one item from the 'novelty' factor.

Table 6: Results of exploratory factor analysis

\begin{tabular}{|c|c|}
\hline Factor Characteristics and Items (after EFA) & $\begin{array}{l}\text { Factor } \\
\text { loadings }\end{array}$ \\
\hline \multicolumn{2}{|l|}{$\begin{array}{l}\text { Factor I-Perfectionist, high quality conscious } \\
\text { When buying everyday products, I do not want to make a careless purchase I later wish I had not }\end{array}$} \\
\hline & .678 \\
\hline $\begin{array}{l}\text { When shopping for everyday products, I look carefully to find best value for money (CSI low 14) } \\
\text { Getting very good quality everyday products is very important to me (CSI low 10) }\end{array}$ & .637 \\
\hline When it comes to purchasing everyday products, in general, I usually try to buy the best overall quality (CSI low 40 ) & 577 \\
\hline \multicolumn{2}{|l|}{ Factor 2 -Brand conscious } \\
\hline The higher the price of an everyday product, the better its quality (CSI low 21) & .569 \\
\hline The more expensive everyday product brands are usually my choice (CSI low 29 ) & .566 \\
\hline The most advertised everyday product brands are usually very good choices. (CSI low 36 ) & .534 \\
\hline \multicolumn{2}{|l|}{ Factor 3 - Confused by overchoice } \\
\hline The more I learn about everyday products, the harder it seems to choose the best (CSI low 25) & .705 \\
\hline There are so many everyday product brands to choose from that often I feel confused (CSI low 32) & 694 \\
\hline All the information I get on different everyday products confuses me (CSI low 7) & .636 \\
\hline It's hard to choose which stores to shop at for everyday products. (CSI low 16) & .601 \\
\hline \multicolumn{2}{|l|}{ Factor 4-Rational, price conscious } \\
\hline When it comes purchasing everyday products, I try to get the very best or perfect choice (CSI low 45) & .613 \\
\hline I am very cautious about trying new everyday products (CSI low 11) & .582 \\
\hline I make a special effort to choose the very best quality everyday products (CSI low 19) & .524 \\
\hline \multicolumn{2}{|l|}{ Factor 5 -Impulsive } \\
\hline I shop quickly for everyday products, buying the first product or brand I find that seems good enough (CSI low 35) & .726 \\
\hline Investigating new brands of everyday products is generally a waste of time (CSI low 34) & .715 \\
\hline I really don't give my everyday product purchases much thought or care (CSI low 28) & .694 \\
\hline \multicolumn{2}{|l|}{ Factor 6-Habitual, brand loyal } \\
\hline I have favourite everyday product brands I buy over and over (CSI low 17) & .615 \\
\hline Once I find an everyday product brand I like, I stick with it (CSI low 26) & .554 \\
\hline Shopping around everyday products wastes my time (CSI low 3) & 515 \\
\hline \multicolumn{2}{|l|}{ Factor 7 -Novelty/fashion conscious } \\
\hline When I see a new brand of everyday products somewhat different from usual, I in & .676 \\
\hline I am willing to change brands when buying everyday products (CSI low 33) & .634 \\
\hline I am the kind of person who would try a new everyday product (CSI low 2) & .615 \\
\hline I would buy a new or different brand of an everyday product just to see what it is like (CSI low 27) & . 568 \\
\hline I enjoy taking chances in buying unfamiliar brands of everyday products just to get some variety (CSI low 20) & . 539 \\
\hline I would rather wait for others to try a new store than try it myself in making my everyday product purchases (CSI low & .525 \\
\hline & 516 \\
\hline I would be worried about trying a new everyday product (CSI low 44$)^{*}$ & \\
\hline \multicolumn{2}{|l|}{ Factor 8-Recreation conscious } \\
\hline I enjoy shopping for everyday products just for the fun of it (CSI low 37) & .682 \\
\hline Going shopping for everyday products is an enjoyable activity for me (CSI low 30) & .658 \\
\hline Shopping around stores wastes my time (CSI low 22)* & .637 \\
\hline I would take advantage of the first opportunity to find out more about a new store selling everyday products I wanted & \\
\hline chase (CSI low 39) & .619 \\
\hline
\end{tabular}

The eight-factor solution explained $82 \%$ of the variance. Results of the exploratory factor analysis indicated that most of the factors had good internal consistency, notably 'perfectionist' $(\alpha=.795)$, 'confused' $(\alpha=.841)$, 'impulsive' $(\alpha$ $=.779)$, 'novelty' $(\alpha=.821)$, 'recreational' $(\alpha=.741)$, 'habitual' ( $\alpha=.771)$, 'rational' $(\alpha=.771)$ decision-making styles. Only the 'brand conscious' factor displayed a poor internal consistency with Cronbach's alpha coefficient of .621. Therefore, the 'brand conscious' decision-making style was not recognised in this study and not included in the confirmatory factor analysis.

\subsubsection{Results of Confirmatory Factor Analysis (CFA)}

CFA was conducted for each seven consumer decision-making style factors by running single-factor congeneric models. The indices of goodness-of-fit showed that all the models were satisfactory (see Table 7). 
Table 7: Fit statistics for the individual factor of the CFA

\begin{tabular}{lccccccc}
\hline Model & $\begin{array}{c}\text { CMIN } \\
\text { /DF }\end{array}$ & $\begin{array}{c}\text { G } \\
\text { FI }\end{array}$ & $\begin{array}{c}\text { AG } \\
\text { FI }\end{array}$ & $\begin{array}{c}\text { T } \\
\text { LI }\end{array}$ & $\begin{array}{c}\text { C } \\
\text { FI }\end{array}$ & $\begin{array}{c}\text { RMS } \\
\text { EA }\end{array}$ & $\begin{array}{c}\text { SR } \\
\text { MR }\end{array}$ \\
\hline Perfecti & 1.751 & 0. & 0.9 & 0. & 0. & 0.05 & 0.04 \\
onist & & 99 & 6 & 93 & 95 & & \\
Confuse & 1.591 & 0. & 0.9 & 0. & 0. & 0.05 & 0.04 \\
d & & 96 & 5 & 91 & 95 & & \\
Rational & 1.641 & 0. & 0.9 & 0. & 0. & 0.05 & 0.03 \\
& & 99 & 6 & 98 & 93 & & \\
Impulsi & 1.671 & 1. & 0.9 & 0. & 0. & 0.04 & 0.05 \\
ve & & 00 & 7 & 93 & 97 & & \\
Habitual & 1.731 & 1. & 0.9 & 1. & 0. & 0.05 & 0.04 \\
& & 00 & 9 & 00 & 98 & & \\
Novelty & 1.651 & 1. & 0.9 & 0. & 0. & 0.04 & 0.05 \\
& & 00 & 7 & 98 & 98 & & \\
Recreati & 1.732 & 1. & 0.9 & 0. & 0. & 0.05 & 0.04 \\
on & & 00 & 8 & 93 & 99 & & \\
\hline
\end{tabular}

\subsubsection{The Respecified Seven-Factor Model of the CSI}

Finally, the respecified seven-factor model of consumer styles inventory consists of 24 items and seven factors are shown in figure 2. Overall, eight items were deleted to achieve a better fit. One item was removed from the 'perfectionist' factor due to insignificant fit as suggested by MIs (e.g., "CSIlow 40: When it comes to purchasing everyday products, in general, I usually try to buy the best overall quality"). One item was deleted from the 'confused' factor, which significantly improved the model (e.g., "CSIlow 16: It's hard to choose which stores to shop at for everyday products"). All three items were retained for the 'rational', 'impulsive', and 'habitual' factors. However, four items were deleted from 'novelty' (e.g., "CSIlow 33: I am willing to change brands when buying everyday products", "CSIlow 20: I enjoy taking chances in buying unfamiliar brands of everyday products just to get some variety.", "CSIlow 18: I would rather wait for others to try a new store than try it myself in making my everyday product purchases", and "CSIlow 27: I would buy a new or different brand of an everyday product just to see what it is like") and two items from 'recreation' factor (e.g., "CSIlow 22: Shopping around stores wastes my time", and "CSIlow 39: I would take advantage of the first opportunity to find out more about a new store selling everyday products I wanted to purchase").

Chi-square $=2.472 . \mathrm{df}=181, \mathrm{p}=.003, \mathrm{CMIN} / \mathrm{DF}=2.109, \mathrm{GFI}$ $=0.907, \mathrm{AGFI}=1.00, \mathrm{TLI}=.979, \mathrm{CFI}=0.992, \mathrm{RMSEA}=.055$
Figure 2: A respecified seven-factor CFA model of consumer styles inventory (low-involvement purchase)

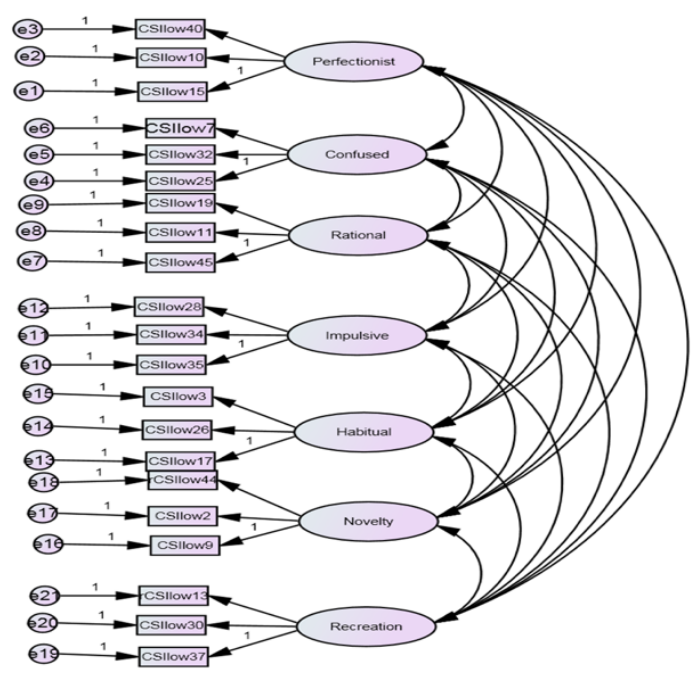

\section{Discussion}

The current study has extended the applicability of the CSI to a non-student population in Australia with a particular interest in comparing high and low involvement purchases. In the following, the paper discusses the significant findings of this research.

\subsection{High Involvement (E.G., Automobiles)}

The results of this study found that only two factors ('brand' and 'habitual') of the original CSI model (Sproles and Kendall 1986) were retained and other factors such as 'investigation process', 'information search', 'value within budget', and 'innovation consciousness' factors were also confirmed for Australian consumers. The possible explanation of these inconsistent findings could be using the automobile or high involvement purchases. For this research, consumers were asked concerning automobiles, whereas, in Sproles and Kendall's study, consumers were not given any choice of specific products. Therefore, it was more in general purchase behaviour.

Consumer decision-making styles for high involvement or automobile purchase are complex problem-solving process (Quester et al., 2007). For example, automobile purchase is likely to be characterised by (a) active information seeking about various brands (Peterson and Merino 2003); (b) major comparison of product attributes (Radder and Hiuang 2006); (c) unique preferences for a particular brand, e.g., brand loyalty (Dholakia, 2001); (d) choices that are likely to be made with a high degree of awareness (Greenleaf and Lehmann 2005) and (e) a result of comprehensive/thorough investigation process.

The findings of this research are relatively realistic and consistent with recent consumer behaviour studies. For 
example, this study found consumers engage in extensive information search (factor 2), go through an investigation process (factor 1), require knowledge, preparation, and enough time to process and evaluate the budget (factor 4) to reach high involvement/automobile purchase decision (see, Bosnjak, 2010; Chen and Quester 2015).

Most of the original factors generated by Sproles and Kendall (1986) are relatively out-of-date and irrelevant in the current context. For example, the original factors, such as 'price' and 'quality' are not the most critical factors in relation to automobile purchases. The research found Australian consumers are not very reluctant to pay a high price for quality cars. In contrast, nowadays, consumers are more interested in guarantee, warranty, innovation, sustainability and other trends associated with automobile purchase behaviour (Shepherdson, 2010). The original 'impulsive' factor was not found in this research. To provide further support to the findings, consumers are less likely to be impulsive in relation to high risk or high involvement purchases (Uncles, 2011). The original CSI requires further modification if to be used for high involvement purchases. For instance, relevant factors parallel with the current contemporary issues such as environmental sustainability, health consciousness, corporate social responsibility (CSR) need to be added. Furthermore, in relation to automobile purchases, the factors such as ecofriendliness/vehicle, solar-powered engine, green cars, and innovation consciousness might be good have (Park et al., 2010; Kumar et al., 2011).

This is also relatively consistent with the findings of this study. 'Innovation consciousness' was proven to be one of the most reliable and valuable scales for Australian consumers' automobile purchase decision-making styles. The study found that Australian consumers prefer more innovative features, design, trends and new technology in their automobiles. This is excellent news for automobile manufacturers because automobile companies in Australia have been focusing on new technology such as eco-friendly (Toyota Prius) and high performance (Holden, Nissan and Ford) vehicles.

Table 8: Consumer decision-making styles identified within selected seminal studies

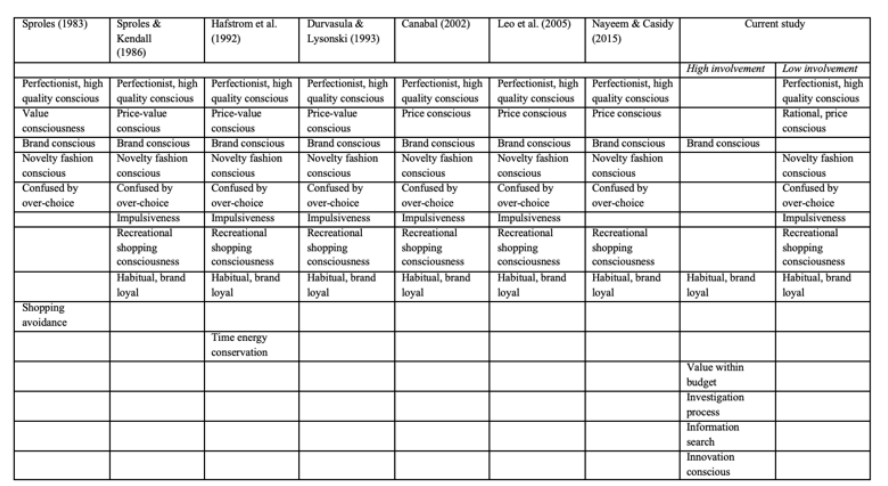

Furthermore, Australian economic culture is based on more technology and information libraries than several other countries and cultures. Historically, Australia has been blessed with natural resources, which helps it be self-sufficient and, therefore, economically more developed. Consequently, consumers are more confident and prefer innovation and change in their purchasing behaviour.

\subsection{Low Involvement (e.g., Confectionary)}

The current research confirmed seven out of eight factors from the original CSI, which is broadly consistent with other studies shown in Table 8, suggesting that consumers in the USA and Australia tap into somewhat similar cognitive dimensions about purchase decision-making. CFA has confirmed that seven factors are adequately unidimensional. In this study, six factors were named in line with the original CSI (Sproles and Kendall 1986) because they mirrored similar decision-making styles within the Australian sample. These six factors, namely, 'perfectionist', 'confused', 'impulsive', 'habitual', 'novelty', and 'recreational', also showed acceptable reliability. Compared to the original study (Sproles and Kendall 1986), the similarities found in this research suggest that Australian consumers are similar to American consumers in their decisionmaking style and found to be more generalizable and valid.

One new factor ('rational') emerged. This factor has proven to be a distinct element of the Australian sample's decisionmaking style, with a Cronbach's alpha of .771. It is interesting to note that Australian consumers might adopt a rational decision-making style for confectionary products. However, the 'brand conscious' factor was not recognised in this study, consistent with previous studies' results (Hiu et al., 2001). This is also consistent with the argument that customers may spend more time and effort choosing between functional features of a product (e.g., chocolate-coated vs non-chocolate coated biscuits) than comparing different brands (Uncles, 2011), and that the customer profiles of directly competing brands rarely differ (Uncles et al., 2012). The items retained for the 'habitual' factor are all from the original CSI 'habitual decision-making style' factor. This result is inconsistent with Hiu et al. (2001), whose study found that the 'habitual' dimension obtained a very low reliability of 0.4 . In light of these findings, it is worth noting that Australian consumers might not spend too much time researching everyday products and therefore engage in repeat purchases to minimise their cognitive effort.

In the current study, the confused/over-choice dimension had the highest reliability, suggesting that it is an essential consideration for Australian consumers. Various factors may contribute to confusion - from the abundance of promotional information into the array of competing brands in the market. The success of hypermarkets and mega-stores in the Australian retail landscape affords consumers considerably more meaningful choices in the form of extensive product displays 
accompanied by considerable point-of-scale information. Thus the potential for information overload is very real.

\section{Managerial Implications}

By adapting CDMS separately for high and low involvement products, this research provides managers with an improved CDMS that can better understand Australian consumers' decisions and help develop marketing strategies in the automotive and confectionary markets. The findings of this research can have implications for high involvement purchases such as solar panels, rainwater tanks, electric, hybrid, and biodiesel cars and low involvement products sold by discount retailers.

Using the current research findings that Australian consumers engage in extensive 'information search' and are 'Innovation consciousness' in their purchase of high involvement products, managers can provide product-related information that would support the transitions from prospects to customers. Failing to provide extensive information (cost, technical, legal, social, environmental etc.) for high involvement and innovative products would prevent sales to Australian customers. Managers can employ internet-based, smartphone and sales lead technologies to communicate with consumers. Sales of Environmental and Green high involvement products such as solar panels have grown at a rate of $7 \%$ in Australia (IBIS World 2019). Australian consumers engage in an extensive information search before purchasing high involvement products. Australians have embraced new high involvement products such as solar panels, rainwater tanks, electric, hybrid and bio-diesel cars at a much higher rate than consumers in other developed economies. The findings of this research support the suggestion that managers can devise segmented marketing strategies based on the framework for CDMS and high involvement products that have been tested.

The high Cronbach's alpha score of .771 associated with Australian consumers' 'rational conscious decision-making style' demonstrates that they employ cognitive rather than emotional behaviour to purchase low-involvement products. Australian consumers demand value for money in their purchase of low involvement products. They understand that generic and non-national brands can perform similarly to popular brands. Australian consumers do not necessarily seek high brand equity of low involvement products/brands. Understanding that Australians are heavily indebted at a rate of $\$ 79,000$ per capita (ABS 2013) provides reasons that Australians are 'rational' low involvement products purchasers. The rapid market growth of discount retailers such as Aldi, Chemist Warehouse, My Chemist, Pharmacy 4 Less and future entry of Lidl can be linked to the 'rational conscious decisionmaking style' for Australian consumers. Knowing that Australians are 'rational' and 'quality conscious' buyers, retailers of discount retail stores can employ CDMS for lowinvolvement products to analyse customers' needs and develop segmented marketing strategies. This would enable managers to further understand the purchasing of low involvement products through the analytical lens of 'rational conscious decision-making style' and 'quality consciousness'.

\section{Limitations and Future Research Directions}

Previous CDMS frameworks are not comprehensive enough in analysing consumers' purchase of high and low involvement products. Since product involvement has implications for CDMS (Bauer et al., 2006), an improved methodology must be developed. CDMS developed by Sproles and Kendall (1986), Durvasula and Lynsonski (1993), Canabal (2002), and Leo et al. (2005) are mainly frameworks that analyse consumer purchase generically. Using these existing CDMS frameworks as an analytical lens, managers would not accurately analyse the decision processes associated with high-and-low involvement products, which have polarity differences in automobile and confectionary relations. Even though this research has adapted CDMS to high and low involvement products, Sproles and Kendall's (1986) omitted environmental, social and multicultural factors because these were not significant concerns for marketers in the 1980's. Zeitgeist's current environmental and social responsibilities have transformed Australian consumers and impacted their purchasing styles.

Nowadays, consumers are concerned about environmental and social issues, and they adjust their CDMS accordingly. Consumers purchase both high and low involvement products based on reduced environmental and social impacts. Environmental credibility, accreditations, $\mathrm{CO} 2$ offsetting, recycling are among some of the factors that affect CDMS. Since the growth of environmental and green products are expected to grow by $3.6 \%$ and USD 1 Trillion in revenue (EBI 2020), it is imperative that researchers and managers analyse CDMS linked to environmental and social factors.

Australia and many other Western countries have seen their demographics changed due to multi-culturalism. For instance, 6.6 million Australian residents or $28 \%$ of the Australian population, were born outside Australia (ABS 2019); 34.3\% of the Australian population had both parents born overseas (ABS 2020). The global halal market is worth approximately USD 2.3 trillion (Hughes and Malik 2012). Research by Regenstein and Chaudry (2003), Ahmed (2008), Lada et al. (2009) reveals that Halal and Kosher certification is essential in purchasing decisions for certain groups of Australian consumers.

CDMS in its various current forms Sproles (1983), Sproles and Kendall (1986), Hafstrom et al. (1992), Durvasula and Lynsonski (1993), Canabal (2002), Leo et al. (2005) and Nayeem and Casidy (2015) are insufficient in analysing CDMS related to environmental, social and multiculturalism concerns. Therefore, as environmental, social and multiculturalism factors are nowadays established relations, the CDMS 
developed in 1986 is an obsolete analytical framework for consumer behaviour researchers and marketing managers. Future research opportunities could develop CDMS frameworks that include environmental, social and multiculturalism variables and subscales.

\section{References}

- Azizi, S. and Makkizadeh, V. (2012). Consumer decisionmaking styles: The Case of Iranian Young Consumers. Journal of Management Research, 4 (4), 88-111.

- Baoku, L., Cuixia, Z. \& Weimin, B. (2010). An impirical study on the deciosn-making styles of the China peasant consumers. Journal of Consumer Marketing, 27 (7), 629637.

- $\quad$ Bauer, H.S., Sauer, N.E. \& Becker, C. (2006). Investigating the Relationship between Product Involvement and Consumer Decision Making Styles. Journal of Consumer Behaviour, 5(4), 342-354.

- Blackwell, R., D'souza, C., Taghian, M., Minard, P. \& Engel, J. (2006). Consumer Behaviour: An Asia Pacific Approach, Thompson Learning Australia, South Melbourne, Australia.

- Browne, B.A. \& Kaldenberg, D.O. (1997). Conceptualizing self-monitoring: links to materialism and product involvement. Journal of Consumer Marketing, 14 (1), 31-44.

- Canabal, M.E. (2002). Decision Making Styles of Young South Indian Consumers: An Exploratory Study. College Student Journal, 36 (1), 1-12.

- Chen, S. \& Quester, P.G. (2015). The relative contribution of love and trust towards customer loyalty. Australasian Marketing Journal, 23, 13-18.

- Cuoco, D. and Liu, H. (2000). Optimal Consumption of a Divisible Durable Good. Journal of Economic Dynamics \& Control, 24, 561-613.

- Dholakia, U.M. (2001). A Motivational Process Model of Product Involvement and Consumer Risk Perception. European Journal of Marketing, 35 (11/12), 1340-1362.

- Easley, R.W., Madden, C.S. \& Dunn, M.G. (2000). Conducting Marketing Science: The Role of Replication in the Research Process. Journal of Business Research, 48, 83-92.

- Geuens, M., De Pelsmacker, P. \& Faseur, T. (2011). Emotional advertising: revisiting the role of product category. Journal of Business Research, 64 (4), 418-426.

- Gorsuch, RL. (1983). Factor Analysis, 2nd edn, Lawrence Erlbaum Associates, Hillsdale, NJ.

- Greenleaf, E. \& Lehmann, D. (2005). Reasons for Substantial Delay in Consumer Decision Making, Journal of Consumer Research, 22,186-199.

- Grewal, R., Cline, T.W. \& Davies, A. (2003). Early-Entrant Advantage, Word-of-Mouth Communication, Brand Similarity, and the Consumer Decision Making Process. Journal of Consumer Psychology, 13 (3),187-197.
- Hanzaee, K.H. \& Aghasibeig, S. (2008). Generation Y Female and Male Decision Making Styles in Iran: Are they Different? International Review of Retail, Distribution and Consumer Research, 18 (5), 521-537.

- Holmes, H.H. \& Crocker, E.K. (2007). Predispositions and the Comparative Effectiveness of Rational, Emotional and Discrepant Appeals for Both High Involvement and Low Involvement Products. Journal of the Academy of Marketing Science, 15, 27-35.

- Kline, R.B. (2005). Principles and Practice of Structural Equation Modeling, 2nd edn, The Guilford Press, NY.

- Kuenzel, J. \& Musters, P. (2007). Social interaction and low involvement products. Journal of Business Research, 60 (8), 876-883.

- $\quad$ Kumar, S., Kwon, H., Choi, K., Lim, W., Cho, JH, Tak, K. \& Moon, L.L. (2011). An eco-friendly cryogenic fuel for sustainable development. Applied Energy, 88 (12), 42644273.

- $\quad$ Lada, S., Tanakinjal, G.H. \& Amin, H. (2009). Predicting intention to choose halal products using theory of reasoned action. International Journal of Islamic and Middle Eastern Finance and Management, 2 (1), 66-76.

- $\quad$ Leo, C., Bennett, R. \& Hartel, E.J. (2005). Cross Cultural Differences in Consumer Decision Making Styles. Cross Cultural Management. 12 (3), 32-61.

- Lysonski, S. \& Durvasula, S. (2013). Consumer decisionmaking styles in retailing: evolution of mindsets and psychological impacts. Journal of Consumer Marketing, 30 (1), 75-87.

- $\quad$ Lysonski, S., Durvasula, S. \& Zotos, Y. (1996). Consumer Decision Making Styles: A Multi Country Investigation. European Journal of Marketing, 30 (12), 10-21.

- Mitchell, V.W, and Bates, L. (1998). UK Consumer Decision Making Styles. Journal of Marketing Management, 14, 199-225.

- Mittal, B. (1995). A Comparative Analysis of Four Scales of Consumer Involvement. Psychology \& Marketing, 12 (7), 663-682.

- $\quad$ Mittal, B. \& Lee, M. (1989). A Causal Model of Consumer Involvement. Journal of Economic Psychology,10, 363389.

- Nayeem, T. \& Casidy, R. (2013). The role of external influences in high involvement purchase behaviour.

- $\quad$ Marketing Intelligence and Planning, 31(7), 732-745.

- Nayeem, T. \& Casidy, R. (2015). Australian consumers' decision-making styles. Australasian Marketing

- Journal, 23, 67-74.

- Nayeem, T. (2012). Cultural Influences on Consumer Behaviour. Journal of Business Management, 7

- (21), 78-91.

- Nunally, J.C. (1978). Psychometric Theory, 2nd edn, McGraw-Hill Book Company, NY.

- O'Cass, A. (2000). “An Assessment of Consumers Product, 
Purchase Decision, Advertising and Consumption Involvement in Fashion Clothing. Journal of Economic Psychology, 21 (5), 545-576.

- Okumus, B., Okumus, F. \& McKercher, B. (2007). Incorporating Local and International Cuisines in the Marketing of Tourism Destinations: The Cases of Hong Kong and Turkey. Tourism Management, 28 (1), 253-261.

- Park, C. \& Kim, Y. (2003). Identifying Key Factors Affecting Consumer Purchase Behaviour in an Online Shopping Context. International Journal of Retail \& Distribution Management, 31 (1), 16-29.

- Park, F.E., Yu, F. \& Zhou, X. (2010). Consumer innovativeness and shopping styles. Journal of Consumer Marketing, 27 (5), 437-446.

- Peterson, R.A. \& Merino, M.C. (2003). Consumer Information Search Behaviour and the Internet. Psychology \& Marketing, 20 (2), 99-121.

- Quester, P., Neal, C. \& Hawkins, D. (2007). Consumer Behaviour Implication for Marketing Strategy, 5th edn, McGraw-Hill Irwin, North Ryde, NSW.

- Radder, L., Li, Y. \& Pieterson, J.J. (2006). Decision Making Styles of Young Chinese, Motswana and Caucasian Consumers in South Africa: An Exploratory Study. Journal of Family Ecology and Consumer Sciences, 34, 20-31.

- $\quad$ Radder, L. \& Hiuang, W. (2008). High involvement and Low involvement Products: A Comparison of Brand Awareness among Students at a South African University.
Journal of Fashion Marketing and Management, 12 (2), 232-243.

- Shamdasani, P.N., Stanaland, A.J.S. \& Tan, J. (2001). Location, Location, Location: Insights for Advertising Placement on the Web. Journal of Advertising Research, July/Aug, 7-21.

- $\quad$ Sproles, G.B. \& Kendall, E.L. (1986). A Methodology of Profiling Consumer Decision Making Styles”, Journal of Consumer Affairs, 20 (2), 267-279.

- Tanksale, D., Neelam, N. \& Venkatachalam, R. (2014). Consumer decision-making styles of young adult consumers in India. Social and Behavioural Sciences, 133, 211-218.

- Thogersen, J., Jorgensen, A.K. \& Sandager, S. (2012). Consumer decision making regarding a 'green' everyday product. Psychology and Marketing, 29 (4), 187197.

- Uncles, M.D. (2011). Understanding brand performance measures. In: Uncles, M.D. (Ed.) Perspectives on Brand Management. Tilda University Press, Melbourne, Australia.

- Uncles,M., Kennedy, R., Nenycz-Thiel,M., Singh, J. \& Kwok, S. (2012). In 25 years, across 50 categories, user profiles for directly competing brands seldom differ. Journal of Advertising

- $\quad$ Research, 52 (2), 252-261.

- Zaichkowsky, J.L. (1986). Conceptualizing Involvement. Journal of Advertising, 15 (2), 4-34. 